\title{
A Hybrid Model to Alleviate Unemployment and Poverty in South Africa
}

\author{
P. C. Enwereji ${ }^{1} \&$ D. E. Uwizeyimana ${ }^{1}$ \\ ${ }^{1}$ School of Public Management, Governance \& Public Policy, College of Business and Economics, University of \\ Johannesburg, South Africa \\ Correspondence: P. C. Enwereji, School of Public Management, Governance \& Public Policy, College of Business \\ and Economics, University of Johannesburg, South Africa.
}

Received: April 9, 2021

Accepted: June 23, 2021

Online Published: October 28, 2021

doi:10.5430/ijfr.v12n5p265

URL: https://doi.org/10.5430/ijfr.v12n5p265

\begin{abstract}
Poverty and unemployment are considered social threats in South Africa as the rate keeps on escalating while few measures are implemented to alleviate the trend. This study devised a hybrid model to reduce the rate of poverty and unemployment in South Africa. The Human Capital Theory formed the theoretical base of this study, which explained the need for the government to invest in education to improve the chances of gaining employment to reduce poverty. The study adopted a quantitative approach and data were collected from only secondary sources. Major findings disclosed that the poverty rate in South Africa is at $49.2 \%$ while $64.2 \%$ of South African blacks remain poor. The study revealed that the unemployment rate is at $30.1 \%$ in the first quarter of 2020 while provinces such as Eastern Cape (40.5\%) and the Free State (38.4\%) have the highest share of unemployment in the country. The meta-analysis conducted revealed that improvement is needed in areas such as legislation and labour laws, entrepreneurial development, youth development policies, common vision and leadership, sectoral development, business climate, acquisition of skills and education, engagement management, and strategic management. This is in an endeavour to reduce poverty and unemployment rate in South Africa.
\end{abstract}

Keywords: poverty, unemployment, economic development, South Africa

\section{Introduction}

The continuous escalating unemployment rate remains a worrisome issue in South Africa as only a few percentages of youths (27.2\%) are employed in the mainstream economy (Shanker et al., 2015). The Department of Trade and Industry (DTI) (2019), upholds that these unemployed persons are likely to depend on the provincial maintenance grants for survival. This social menace puts pressure on the resources of the government and correspondingly raises questions about South African social and economic stability. According to Statistics South Africa (2020), the unemployment rate was at $24.5 \%$ in 2015 , it rose to $26.5 \%$ in $2016,26.7 \%$ in $2017,27.1 \%$ in $2018,29.1 \%$ in 2019 , and $35.1 \%$ in the second quarter of 2020. This significantly portrays that the level of unemployment as recorded by the Statistics Department is among the highest in the world. The evidence of unemployment presents South Africa with a daunting policy challenge and if the relevant policy frameworks are not implemented to educate and provide the needed skills for the youths, unemployment and insecurity will persist, which could be subject to intolerable tensions (World Bank, 2015).

The unemployment rate is highly concentrated amongst youths between the ages of 15-24 years and this accounts for $50.4 \%$ (2015), 50.9\% (2016), 51.1\% (2017), 54.7\% (2018), 58.1\% (2019), and 59\% in 2020 (STATS SA, 2020). Furthermore, STATS SA (2020), pinpoints that the rate of youth unemployment subjects the youths to live below the poverty line thus finding it difficult to earn a better living. Since the achievement of democracy in 1994, South Africa's development trajectory has not absorbed the youth labour force at the needed rate and this has escalated the poverty and inequality levels regardless of the substantial social grants and services being deployed to the residents (Ramaphosa, 2020). Although attempts have been made by the government to establish national youth development policies that could guarantee equal opportunities for youths to be employed in the mainstream economy, the rate of unemployment is disconcertingly high (Maswanganyi, 2015). The present unemployment level amongst South African youths has replicated what the youths faced during the Apartheid era and this poses a great concern to the 
government and the policymakers (Meyer, 2014; Shanker et al., 2015). This ugly situation calls for a new or hybrid model to ensure that change occurs in all aspects of the economy.

Poverty, according to Statistics South Africa (2018), depicts a sheer lack of adequate resources to cater to the essentials of life including food, shelter, clothes, and water. It could also be expanded in the contemporary world to include access to basic health care, employment, and even transportation. However, the World Bank (2015), maintains a measure known as the International Poverty Line and sets out the concept of extreme poverty as anyone living on less than US\$ 1.90 per day. South African residents continue struggling to rise above the poverty line and the World Bank affirms that South Africa is a nation with a per capita income equivalent to that of Botswana, Brazil, Malaysia, or Mauritius. Despite the approval of relevant developmental policies, most South African households remain poor and there is an enduring vulnerability to operating below the poverty line (Van der Westhuizen \& Swart, 2015). This was confirmed by the Living Conditions Survey (LCS) conducted by Statistics South Africa in 2015 where it was discovered that $49.2 \%$ of adults live just below the Upper-Bound Poverty Line (UBPL) (STATS SA, 2015). Despite substantial progress over the last five years to eradicate poverty, many South African households have unacceptable access to energy, water, shelter, health care, and education.

Concerning this situation, this study proposed a hybrid model that serves as a guideline to policymakers to alleviate unemployment and poverty in South Africa. If poverty, inequality, and unemployment are to be addressed in South Africa as sustained by Ramaphosa (2020), the discovery of employment paths for the youths is critical to transforming the future growth trajectory.

\section{Theoretical Background}

The Human Capital Theory, also known as the theory of earnings is one of the main determining factors of poverty. Becker and Mincer formulated this theory in the early 1960s which describes the decisions of individuals to invest in human capital. This theory assumes that the success of countries could be determined by the physical and human capital stock (Psacharopoulos \& Woodhall, 1997). The various investments individuals make in education and training are clarified in terms of their anticipated returns from the investment. Human Capital Theory relies on the premise that formal education is highly instrumental and appropriate for improving a population's productive potential (Becker, 1993). The theory of human capital emphasizes how education improves worker productivity and performance by growing the amount of cognitive stock of economically efficient human potential which is a result of instinctive abilities and human investment. Attempts to stimulate investment in human resources have been shown to contribute to strong economic development for nations (Frankenberger, 1996). These investments were seen for individuals to produce returns in the form of individual economic accomplishments. Many economists believe that it is the nation's human resources that ultimately decide the character and speed of its economic and social growth, not capital or its material resources. Human resources are the absolute cornerstone of nations' wealth (McKernan \& Ratcliffe, 2002). Capital and natural resources cannot be completely regarded as production factors but the labour force remains the social actors that ensure economic development and growth. This implies that the Human Capital Theory can be applied with nations' educational systems to enhance development.

This theory expresses the need for the South African government to increase the budgets on education and invest in human capital to increase employment opportunities. Consequently, the basic needs of the people should be provided for, as well as, exposing them to more economic activities to improve the opportunity of gaining employment in an endeavour to reduce the poverty ravaging the country.

\section{Research Methodology}

The non-empirical methodological technique was adopted in this study and this was applied by reviewing secondary sources in a view to finding solutions to the phenomenon under investigation (Leedy \& Omrod, 2014). In this regard, the study reviewed vast literature and previous policy documents related to poverty and unemployment and identified possible gaps and factors to reduce poverty and unemployment. The study collected data on unemployment and poverty rates from Statistics South Africa to highlight the level of unemployment and poverty. Quantitative research principles were applied in this study. In the research method, the researcher engaged in a systematic literature review and constructed a meta-analysis that highlighted several views of authors in the South African context to alleviate poverty and unemployment. Several searches were made on the internet through Web of Science and EBSCOhost and keywords such as poverty, poverty in South Africa, the poverty rate in South Africa, unemployment, unemployment in South Africa, and the unemployment rate in South Africa was made to find solutions to the problem of the study. The inclusion criteria of articles used in this study comprised peer-reviewed articles published in the English language, articles focused on unemployment and poverty, and articles focused on youth unemployment, all in the South African context. 
Regarding the research procedure, an assessment of the poverty level in South Africa was made, followed by the assessment of the unemployment status. These were done by comparing the past and recent data of poverty and unemployment rates in South Africa. The initiatives to alleviate unemployment were also made, which traced some soluble policies made by the government to alleviate unemployment. Finally, a meta-analysis was drawn from different authors' perspectives which serve as recommendations to the study. Added to these recommendations are the authors' contributions to decrease the poverty and unemployment rate in South Africa. These were discussed briefly and the study terminated with a conclusion.

\section{Assessment of Poverty Status in South Africa}

Poverty is a major social, economic, and political growth challenge in South Africa and the world at large (Francis \& Webster, 2019). The World Bank (2018), affirms that combating poverty and underdevelopment has always been a core theme of policy in post-apartheid South Africa. Poverty has remained a topical issue in global development policy initiatives, especially in developing countries, it is a concept of multiple dimensions, and as such, efforts to reduce poverty need to be facilitated speedily to rescue humanity (Singh \& Chudasama, 2020). However, South Africa has been fighting to alleviate poverty through a wide variety of programs for more than two decades and these measures include using monetary policy to promote redistributive measures (Mosala, Venter \& Bain, 2017).

The Reconstruction and Development Program initiated in 1993 was the first major poverty reduction scheme adopted for poverty reduction and the present attempts to combat poverty could be traced to the works of our past heroes (Mosala, Venter \& Bain, 2017). However, many initiatives have continued to follow the prescripts of the Reconstruction and Development Program, and the latest of them is the National Development Plan 2030 which is premised to eradicate poverty and describes the country's threefold problem of high poverty and unemployment as a major challenge (STATS SA, 2015). More than two decades after the end of apartheid, the existence of these problems demands comprehension. The rise in poverty in South Africa after two decades of independence demands a thorough evaluation of the nature and causes of poverty and the various measures to eliminate poverty to enhance the living conditions of common South Africans (Van der Westhuizen \& Swart, 2015). This section investigates the status of poverty in South Africa according to provinces and races.

Table 1 presents the poverty headcount and poverty share of adults by province (upper-bound poverty line). The Table depicts that the poverty rate increased from 45.1 in 2009 to 49.2 in 2015 and this portrays that almost half of South Africans are poor. Table 1 further indicates that the Gauteng and Western Cape provinces are the provinces with the least poverty rate while Limpopo and the Eastern Cape are the provinces with the highest rate of poverty. Out of the nine provinces, the Free State and Limpopo are the provinces that have succeeded in reducing the poverty levels from $2.1 \%$ and $2 \%$ respectively in 2009 to 2015 , though poverty continues to soar high in the provinces and this demands immediate attention by the government to enhance the living conditions of the citizenry.

Table 1. Poverty headcount and poverty share of adults by province $2009 \& 2015$ (upper-bound poverty line)

\begin{tabular}{lllll}
\hline Provinces & Headcount (\%) & Share (\%) & Headcount (\%) & Share (\%) \\
\cline { 2 - 5 } & $\mathbf{2 0 0 9}$ & $\mathbf{2 0 0 9}$ & $\mathbf{2 0 1 5}$ & $\mathbf{2 0 1 5}$ \\
\hline Western Cape & 26.7 & 6.9 & 33.2 & 8.2 \\
\hline Eastern Cape & 57.9 & 16.3 & 67.3 & 15.6 \\
\hline Northern Cape & 52.8 & 2.8 & 54.3 & 2.5 \\
\hline Free State & 51.0 & 6.8 & 48.9 & 5.3 \\
\hline KwaZulu-Natal & 52.4 & 23.2 & 60.7 & 22.7 \\
\hline North West & 50.2 & 7.9 & 59.6 & 8.3 \\
\hline Gauteng & 24.6 & 12.9 & 29.3 & 15.8 \\
\hline Mpumalanga & 54.6 & 8.3 & 54.6 & 8.4 \\
\hline Limpopo & 69.5 & 14.9 & 67.5 & 13.4 \\
\hline Total & $\mathbf{4 5 . 1}$ & $\mathbf{1 0 0}$ & $\mathbf{4 9 . 2}$ & $\mathbf{1 0 0}$ \\
\hline
\end{tabular}

Source: Statistics South Africa (2009, 2015) (Compiled by the Author) 
In Figure 1, the percentages of South Africans and households that depend on the social grant for survival due to poverty and unemployment were presented and it could be observed that the total percentage of grant beneficiaries is at $31 \%$ in South Africa while the percentage of households stand at $44.3 \%$. The Eastern Cape and Limpopo are the provinces with the highest number of grant beneficiaries, while Eastern Cape and Northern Cape have the highest number of household beneficiaries. The Gauteng and Western Cape provinces hold the least number of grant beneficiaries, as well as household beneficiaries. However, the current poverty rate (44.3\%) is considered very high and there is a needs for a policy overhaul in an endeavour to create more jobs.

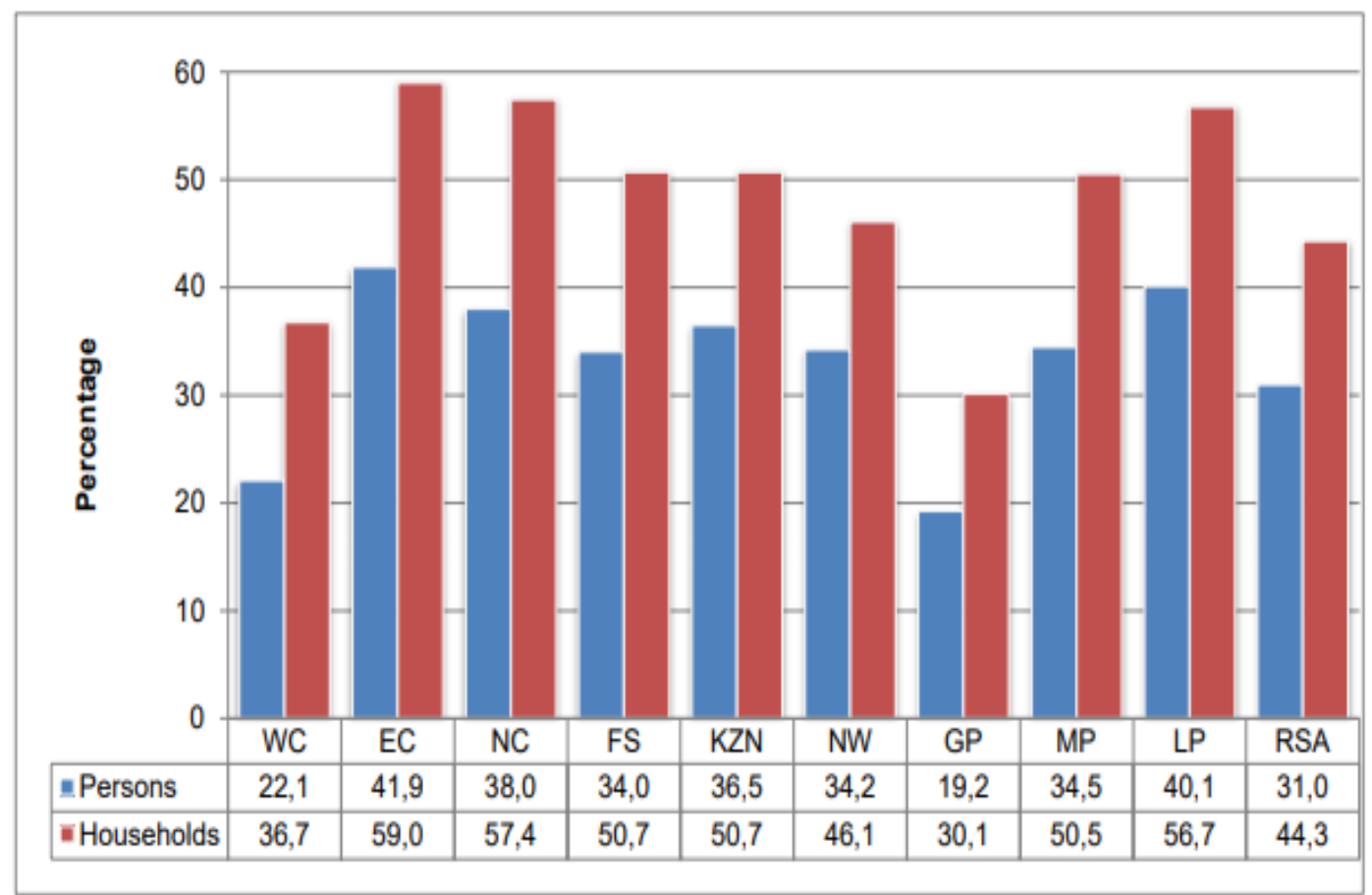

Figure 1. Percentage of individuals and households benefiting from social grants per province, 2018 Source: Statistics South Africa (2018)

Table 2 presents the rate of poverty across racial backgrounds in 2015. It could be observed that more than half of South Africans 55.5\% (30 383 788) are poor. Table 2 also portrayed that black South Africans are the racial group with the highest level of poverty and this was followed by the coloured with 41.3\% (1 989 304). The Whites and Indian/Asians are the races with the least level of poverty. The information contained in this Table is an indication that the government of South Africa should implement soluble initiatives to alleviate poverty, especially in the black-dominated areas to enhance their living standards.

Table 2. Poverty across racial backgrounds (2015)

\begin{tabular}{lll}
\hline Population group & Number & \% of population group \\
\hline African/Black & $28,267,530$ & $64.2 \%$ \\
\hline Coloured & $1,989,304$ & $41.3 \%$ \\
\hline Indian/Asian & 79,460 & $5.9 \%$ \\
\hline White & 47,494 & $1 \%$ \\
\hline South Africa & $30,383,788$ & $55.5 \%$ \\
\hline
\end{tabular}

Source: Stats SA's Poverty Trends in South Africa (2015) 


\section{Assessment of the Unemployment Rate in South Africa}

According to the World Bank (2015), the issue of unemployment has succeeded in reducing the earning opportunities of South Africans, thus undermining social stability and puts unnecessary pressure on its national finances. Meyer (2014), affirms that the creation of jobs enhances economic development and serves as a foundation of a booming economy. Although South Africa has made job creation its top priority development agenda, the account from the World Bank (2019), portrays that unemployment in South Africa has worsened to the extent that only one in three youths holds a secured job (white collar job). Shanker et al. (2015), further confirm that South Africa's unemployment rate among youths is close to $60 \%$, more than double of the national average unemployment rate of $25 \%$. Statistics South Africa (2020), sustains that there are over 50 million people in South Africa and the unemployment rate in the first quarter of 2020 increased to $29.1 \%$ compared to $28.4 \%$ in the last quarter of 2019 . When compared with other countries, Argentina has low unemployment rate with (7.1\%), China (4.1\%), Japan (4.4\%) Mexico (5\%) and (9.8\%) in India (Country Economy, 2014).

The high unemployment rates arising from the poor economic policies are correlated with the apartheid period, marked by deep socio-economic inequality and lack of access to opportunities in the mainstream economy. There is a tremendous need for South Africa to address the existing unemployment ravaging the country as it affects the economy of the country (Centre for Development and Enterprise, 2019). Holding the youth unemployment agenda as a top policy priority as stipulated in NDP will enhance job creation, thus reducing crime and social insecurity. The World Bank (2015), upholds that the creation of sustainable jobs enhances economic development and alleviates poverty, increases productivity and standard of living, integrates sectors in a global context, and promotes social unity. The creation of jobs through diverse measures will resolve the issue of unemployment in South Africa and help the citizens, even in the rural areas, to enhance their living standards as stipulated by the National Development Plan 2030.

Table 3 presents the unemployment rate in South Africa from 2015-2020. It could be observed that the present unemployment rate is at $30.1 \%$ in 2020 . When compared with the unemployment rate in $2015(24.5 \%)$, this depicts that the unemployment rate increased by 5.6\%. The table portrayed that the absorption rate stood at $44.2 \%$ in 2015 and $42.1 \%$ in the first quarter of 2020 and this shows that more actions are needed to inaugurate economic initiatives to create more jobs since the labour force increased from $58.5 \%$ in 2015 to $60.3 \%$ in 2020. Table 3 further portrayed that almost 3 million South African job seekers are discouraged to look for jobs due to frustrations such as inability to secure the desired job and issues related to job mismatch. With regard to the unemployment rate, this study proposes a hybrid model to alleviate unemployment and poverty.

Table 3. The unemployment rate in South Africa from 2015-2020 (Key labour market indicators)

\begin{tabular}{|c|c|c|c|c|c|c|}
\hline & $2015(000)$ & $\begin{array}{l}2016 \\
(000)\end{array}$ & $\begin{array}{l}2017 \\
(000)\end{array}$ & $2018(000)$ & $\begin{array}{l}2019 \\
(000)\end{array}$ & $\begin{array}{c}2020(000) \\
\text { First quarter }\end{array}$ \\
\hline Population aged 15-64 yrs & 36272 & 36905 & 37525 & 38134 & 38727 & 38874 \\
\hline Labour force & 21211 & 21849 & 22051 & 22668 & 23146 & 23452 \\
\hline Employed & 16018 & 16069 & 16171 & 16529 & 16420 & 16383 \\
\hline Formal sector (Non Agric) & 11180 & 11156 & 11244 & 11346 & 11331 & 11282 \\
\hline Informal sector (Non Agric) & 2684 & 2695 & 2808 & 3001 & 2918 & 2921 \\
\hline Agriculture & 860 & 919 & 849 & 849 & 885 & 865 \\
\hline Private households & 1294 & 1299 & 1270 & 1332 & 1286 & 1316 \\
\hline Unemployed & 5193 & 5781 & 5880 & 6139 & 6726 & 7070 \\
\hline Not economically active & 15061 & 15055 & 15474 & 15466 & 15581 & 15422 \\
\hline Discouraged work seekers & 2279 & 2292 & 2538 & 2841 & 2855 & 2918 \\
\hline Other (not economically active) & 12782 & 12763 & 12936 & 12625 & 12726 & 12504 \\
\hline Unemployment rate & $24.5 \%$ & $26.5 \%$ & $26.7 \%$ & $27.1 \%$ & $29.1 \%$ & $30.1 \%$ \\
\hline Absorption rate & $44.2 \%$ & $43.5 \%$ & $43.1 \%$ & $43.3 \%$ & $42.4 \%$ & $42.1 \%$ \\
\hline Labour force participation rate & $58.5 \%$ & $59.2 \%$ & $59.9 \%$ & $59.4 \%$ & $59.8 \%$ & $60.3 \%$ \\
\hline
\end{tabular}

Source: Statistics South Africa (2015-2020) (Compiled by the Author) 
The next table presents employment in the main sectors of industry in South Africa from 2015 to the first quarter of 2020 .

Table 4. Employment in the main sectors of the South African Industries (2015-2020)

\begin{tabular}{|c|c|c|c|c|c|c|}
\hline Industry & $\begin{array}{l}2015 \\
(000)\end{array}$ & $\begin{array}{l}2016 \\
(000)\end{array}$ & $\begin{array}{l}2017 \\
(000)\end{array}$ & $\begin{array}{l}2018 \\
(000)\end{array}$ & $\begin{array}{l}2019 \\
(000)\end{array}$ & $\begin{array}{c}2020 \\
\text { (000) (First } \\
\text { quarter) }\end{array}$ \\
\hline Total & 16018 & 16069 & 16171 & 16529 & 16420 & 16383 \\
\hline Agriculture & 860 & 919 & 849 & 849 & 885 & 865 \\
\hline Mining & 483 & 421 & 411 & 438 & 430 & 436 \\
\hline Manufacturing & 1738 & 1727 & 1791 & 1766 & 1720 & 176 \\
\hline Utilities & 123 & 131 & 149 & 134 & 120 & 116 \\
\hline Construction & 1438 & 1483 & 1390 & 1481 & 1350 & 1343 \\
\hline Trade & 3280 & 3222 & 3240 & 3320 & 3249 & 3320 \\
\hline Transport & 900 & 961 & 1001 & 965 & 1011 & 995 \\
\hline Finance and other businesses & 2273 & 2329 & 2373 & 2611 & 2568 & 2517 \\
\hline Community and social service & 3624 & 3571 & 3691 & 3624 & 3792 & 3759 \\
\hline Private households & 1294 & 1299 & 1270 & 1332 & 1286 & 1316 \\
\hline
\end{tabular}

Source: Statistics South Africa (2015-2020) (Compiled by the Author)

In Table 4, it could be seen that the labour force of South Africa in the first quarter of 2020 is at 16383000 . More so, there is evidence that community and social services, and trade is the highest employer of labour. Utilities, mining, transport, and agriculture are the sectors with the lowest employment capacity. This implies that the government should initiate measures to increase the employment opportunities in these sectors to accommodate the unemployed job seekers.

Table 5 presents the employment and the unemployment rate in all the provinces of South Africa. It could be observed that the unemployment rate of South Africa is at 30.1\% (16 383000$)$ against the labour force of $42.1 \%$ (23 452 000). Table 5 depicts that the Gauteng, KwaZulu Natal and Western Cape provinces are the highest employers of labour. Further analysis portrayed that there have been fluctuations concerning the employment of labour in all the provinces from 2015 to 2020 . There is also a significantly poor increase regarding the employment of labour across the provinces. Concerning the unemployment rate, it could be observed that the Eastern Cape and the Free State are the provinces with the highest level of unemployment $(40.5 \%, 38.4 \%)$ and this is considered high as almost half of the residents are unemployed. The Western Cape and Limpopo provinces are the provinces with the lowest unemployment rates $(20.9 \%, 23.6 \%)$. 
Table 5. Employment and unemployment rates in all the provinces

\begin{tabular}{lccccccc}
\hline & $\mathbf{2 0 1 5}$ & $\mathbf{2 0 1 6}$ & $\mathbf{2 0 1 7}$ & $\mathbf{2 0 1 8}$ & $\mathbf{2 0 1 9}$ & $\mathbf{2 0 2 0}$ & $\begin{array}{c}\text { Current } \\
\text { unemployment } \\
\text { rate }(\mathbf{\%})\end{array}$ \\
\hline South Africa & $\mathbf{1 6 ~ 0 1 8}$ & $\mathbf{1 6 ~ 0 6 9}$ & $\mathbf{1 6 ~ 1 7 1}$ & $\mathbf{1 6 ~ 5 2 9}$ & $\mathbf{1 6 ~ 4 2 0}$ & $\mathbf{1 6 ~ 3 8 3}$ & $\mathbf{3 0 . 1}$ \\
\hline $\begin{array}{l}\text { Labour force (South } \\
\text { Africa) }\end{array}$ & 21211 & 21849 & 22051 & 22668 & 23146 & 23452 & 42.1 \\
\hline Western Cape & 2380 & 2386 & 2492 & 2520 & 2518 & 2501 & 20.9 \\
\hline Eastern Cape & 1411 & 1447 & 1391 & 1375 & 1384 & 1382 & 40.5 \\
\hline Northern Cape & 312 & 298 & 321 & 322 & 335 & 336 & 27.0 \\
\hline Free State & 825 & 757 & 806 & 806 & 785 & 756 & 38.4 \\
\hline KwaZulu-Natal & 2529 & 2541 & 2513 & 2648 & 2664 & 2672 & 26.9 \\
\hline North West & 969 & 959 & 999 & 973 & 992 & 969 & 33.2 \\
\hline Gauteng & 5090 & 5111 & 4991 & 5163 & 5098 & 5134 & 31.4 \\
\hline Mpumalanga & 1191 & 1155 & 1242 & 1245 & 1244 & 1244 & 33.3 \\
\hline Limpopo & 1311 & 1414 & 1417 & 1477 & 1400 & 1387 & 23.6 \\
\hline
\end{tabular}

Source: Statistics South Africa (2015-2020) (Compiled by the Author)

Table 6 presents the youth unemployment statistics from 2015 to 2020. The table depicts that youth unemployment in 2015 was at $50.4 \%$ and rose to $59 \%$ in the first quarter of 2020 - an increase of $8.6 \%$ in just five years. The present percentage of youth unemployment in South Africa (59\%) is considered high and this represents one of the highest youth unemployment rates in the world. It could also be deduced in Table 6 that the labour force is gradually increasing (comparing the labour force in 2015 with 2020) while the absorption rate is decreasing (comparing the absorption rate in 2015 with 2020) and this calls for proper interventions to ensure that more jobs are created to integrate more youths into the mainstream economy to alleviate poverty and unemployment.

Table 6. Labour force characteristics by age group (15-24 years) (2015-2020)

\begin{tabular}{lcccccc}
\hline Dimensions & $\mathbf{2 0 1 5}$ & $\mathbf{2 0 1 6}$ & $\mathbf{2 0 1 7}$ & $\mathbf{2 0 1 8}$ & $\mathbf{2 0 1 9}$ & $\mathbf{2 0 2 0}$ \\
& $\mathbf{( 0 0 0 )}$ & $\mathbf{( 0 0 0 )}$ & $\mathbf{( 0 0 0 )}$ & $\mathbf{( 0 0 0 )}$ & $\mathbf{( 0 0 0 )}$ & $\mathbf{( 0 0 0 )}$ \\
\hline Population 15-24 years & 10300 & 10313 & 10314 & 10303 & 10280 & 10273 \\
\hline Labour force & 2654 & 2715 & 2670 & 2591 & 2692 & 2790 \\
\hline Employed & 1317 & 1333 & 1305 & 1173 & 1127 & 1143 \\
\hline Unemployed & 1337 & 1382 & 1365 & 1417 & 1565 & 1647 \\
\hline Not economically active & 7646 & 7549 & 7644 & 7712 & 7588 & 7483 \\
\hline Unemployment rate & $50.4 \%$ & $50.9 \%$ & $51.1 \%$ & $54.7 \%$ & $58.1 \%$ & $59 \%$ \\
\hline Absorption rate & $12.8 \%$ & $12.9 \%$ & $12.7 \%$ & $11.4 \%$ & $11.0 \%$ & $11.1 \%$ \\
\hline Labour force participation rate & $25.8 \%$ & $26.3 \%$ & $25.9 \%$ & $25.1 \%$ & $26.2 \%$ & $27.2 \%$ \\
\hline
\end{tabular}

Source: Statistics South Africa (2015-2020) (Compiled by the Author)

\section{A Hybrid Model to Alleviate Unemployment and Poverty}

A vast literature review was conducted for this study and nine factors were identified which needs improvement to ensure that more jobs are created in South Africa and this will enhance the rate of employment and reduce poverty in all the provinces. In this regard, a meta-analysis was conducted and seven significant factors were identified by 
different authors as soluble measures to alleviate unemployment in South Africa. Two more factors were added by this study to reduce unemployment and poverty in South Africa. These factors are presented in Table 7 below:

Table 7. Meta-analysis of the study

\section{CONSTRUCTS}

\begin{tabular}{|c|c|c|c|c|c|c|c|c|c|}
\hline Author(s) & 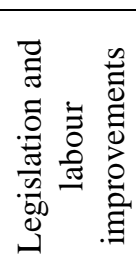 & 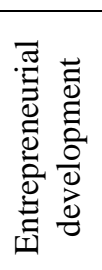 & 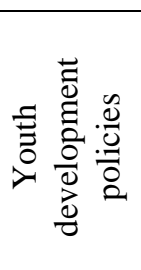 & 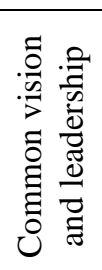 & 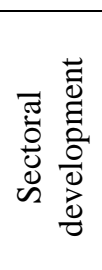 & 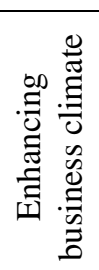 & 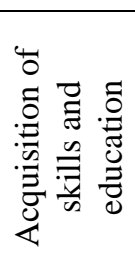 & 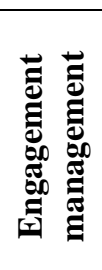 & 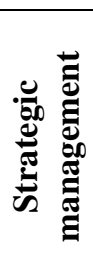 \\
\hline Meyer (2014) & $\sqrt{ }$ & $\sqrt{ }$ & $\sqrt{ }$ & $\sqrt{ }$ & $\sqrt{ }$ & $\sqrt{ }$ & $\sqrt{ }$ & & \\
\hline $\begin{array}{l}\text { Norld Bank } \\
\text { 2015) }\end{array}$ & & & & & $\sqrt{ }$ & & $\sqrt{ }$ & & \\
\hline $\begin{array}{l}\text { Shanker et al. } \\
\text { (2015) }\end{array}$ & $\sqrt{ }$ & $\sqrt{ }$ & $\sqrt{ }$ & & & $\sqrt{ }$ & & & \\
\hline $\begin{array}{c}\text { Maswanganyi } \\
(2015)\end{array}$ & $\sqrt{ }$ & & $\sqrt{ }$ & & & & $\sqrt{ }$ & & \\
\hline $\begin{array}{c}\text { Ferreira \& } \\
\text { Rossouw } \\
(2016)\end{array}$ & $\sqrt{ }$ & & $\sqrt{ }$ & & $\sqrt{ }$ & & & & \\
\hline $\begin{array}{c}\text { Statistics SA } \\
\text { (2017) }\end{array}$ & $\sqrt{ }$ & $\sqrt{ }$ & $\sqrt{ }$ & $\sqrt{ }$ & & $\sqrt{ }$ & $\sqrt{ }$ & & \\
\hline
\end{tabular}

$\begin{gathered}\text { Du Toit et al. } \\ (2018)\end{gathered}$
$\begin{gathered}\text { De Lannoy et } \\ \text { al. (2018) }\end{gathered}$

Source: Compiled by the Author (2020)

According to the meta-analysis presented in Table 7, factors such as legislations and labour improvements, entrepreneurial development, youth development policies, common vision and leadership, sectoral development, enhancing of the business climate, and acquisition of skills and education were identified from different authors' views as the measures to reduce unemployment and poverty in South Africa. Added to these factors are the contributions of this study which are engagement management and strategic management. These factors represent the recommendations of this study to South African government and policy makers, also to other developing countries to alleviate the rate of unemployment and poverty. These factors are briefly expounded upon.

Legislation and labour improvements: Flexible and reasonable labour regulation promotes job creation and economic growth. This study proposes that the government of South Africa should promote relevant legislation and labour improvements to ensure that jobs are created to reduce unemployment and poverty.

Entrepreneurial development: To promote job creation in the informal sector, entrepreneurial development is deemed indispensable. Through entrepreneurial development and the support of SMMEs, many unemployed youths would be engaged in several dimensions of trade and services which will create employment opportunities for jobseekers. 
Nature of youth development policies: To enhance youth empowerment, it demands that the political class should make policies that will favour the youths. This study recommends that policies, regulations, bye-laws and other initiatives should be made to favour youth empowerment to create job opportunities.

Common vision cum leadership: Consistency of vision is paramount in achieving common goals. This study recommends uniformity and consistency of goals by the former and present administrations to achieve unified objectives. New leaders should endeavour to start from the point of departure of the past administration and should not initiate completely new policies. However, policies should be evaluated and augmented with new ones to achieve national objectives.

Sectorial development: The study recommends that all sectors in the economy should be efficiently functional to create jobs for the youths and other jobseekers. Sectors such as utilities, mining, transport, and agriculture are the sectors with the lowest employment capacity and this calls for improvement and investments, especially in the black-dominated areas to strike a balance between the white merchants and indigenous South Africans.

Establishment of enabling business climate: This study recommends that the government should make regulations that will always provide a conducive environment for business activities to survive. There should be an enabling environment for business activities, private and public investments, foreign trade and investment promotion of SMMEs, labour market reforms, tourism, and giving support to the informal sector.

Acquisition of skills and education: Skills acquisition and education are very essential to prepare the youths to meet the demands of the employers. This study recommends that the government should pursue programmes aimed at equipping the youths with the needed skills and expertise for employment. The study further recommends the consistency, uniformity, and suitability of educational systems in South Africa to produce outstanding candidates ready for employment.

This study made a significant contribution which is the inclusion of engagement management and strategic management to alleviate poverty and unemployment. However, these factors would be briefly expounded upon in this study but would be well-explained in the future empirical study.

Engagement Management: Engagement management refers to a process of identifying and educating people to acquire relevant knowledge for a purpose. This study recommends that the youths in the local areas who are not qualified or qualified to have the opportunity to gain employment in the formal sector (especially black-dominated areas) should be identified and engaged by the local officers (employed by the government) to change their psychology and encourage them to acquire the needed skills to be self-reliant.

Strategic management: Strategic management is a futuristic aspect of management that deals with tactical efforts to gain a comparative advantage. It helps to monitor the challenges of organisations and implement efficient measures to resolve the problems of the organisation. Strategic management also involves all aspects of investigative procedures and policy formulations implemented by management to actualise organisational objectives. This study recommends that the leaders should adopt the prescripts of strategic management to ensure that jobs are created to alleviate the rate of unemployment and poverty in South Africa.

The subsequent section presents the conclusion of the study.

\section{Conclusion}

This study examined measures to alleviate poverty and unemployment in South Africa. A qualitative study was adopted to find solutions to the problem of the study. Findings revealed that the rate of poverty and unemployment in South Africa is very high and this has resulted in a high dependency on social grants by the citizens. Inequality has soared high, the youths have taken crime as a means of livelihood while suffering has been the inheritance of the jobseekers. The issue of unemployment as disclosed by this study portrayed an increasing population with a low level of skills acquisition that makes it difficult for most jobseekers to find jobs in the labour market. The labour market needs highly skilled workers to fit into their workspace and this calls for investment in education as explained by the Human Capital Theory. Nations with adequate skillsets are likely to adapt to globalization opportunities, thus taking advantage of emerging opportunities such as new production techniques, new technology, new financial sources, and new information to enhance their economy. There is evidence of slow growth to poverty elasticities as a result of high-income inequality. An increase in access to education or skilled jobs could reduce poverty in the coming years and initiatives aimed at simultaneously enhancing growth and reducing inequalities are likely to be more successful than interventions that only enhance growth or reduce inequalities. The creation of good jobs for the poor would have a greater effect on poverty. 
This study finally submits that the intensifying poverty and unemployment could be alleviated if appropriate measures as identified by this study would be applied by the government. The hybrid model of the study proposes that the government of South Africa should alleviate poverty and unemployment through the enhancement of their legislation and labour laws, entrepreneurial development, youth development policies, common vision and leadership, sectoral development, enhancing of the business climate, and acquisition of skills and education were identified from different authors' views as the measures to reduce unemployment and poverty in South Africa. This study further proposes that the government should apply engagement management and strategic management to reduce poverty and unemployment. Due to gaps in evidence and understanding of what types of initiatives and jobs to be created for the youths, engagement management is proposed to understand the viewpoints of the youths and to know what type of interventions are to be initiated for skill enhancement or acquisition. More so, strategic management is proposed to the public officeholders to survey the internal and external environment and formulate appropriate measures to solve the problems of the society to attain agreed objectives.

The hybrid model is expected to enhance unemployment and also reduce poverty in all sectors of the economy. Public sector strategic management will assist in determining the future challenges limiting the creation of employments while engagement management will assist in identifying the particular needs of the youths. Also, engagement management will help in the promotion of entrepreneurship amongst youths, thus facilitating employment even at the grass root level. This hybrid model is expected to be adopted. As noted in the introduction of this study, if poverty, inequality, and unemployment are to be addressed in South Africa, the discovery of employment paths for youths is critical to transforming the future growth trajectory.

\section{References}

Becker, G. (1991). A treatise on the family. Cambridge and London: Harvard University Press.

Centre for Development and Enterprise. (2019). Agenda 2019: Tackling youth unemployment-before you vote, ask questions, demand answers. Retrieved $8^{\text {th }}$ August 2020, from https://www.cde.org.za/agenda-2019-tackling-youth-unemployment/

Country Economy. (2014). Country statistical comparisons. Retrieved 26th April 2020, from www.countryeconomy.com

Creswell, J. W. (2014). Research design: qualitative, quantitative, and mixed methods approach (4th ed.). CA: Sage Publications.

Du Toit, M., De Witte, H., Rothmann, S., \& Van den Broeck, A. (2018). Contextual factors and the experience of unemployment: A review of qualitative studies. South African Journal of Economic and Management Sciences, 21(1), a2083.

Ferreira, L., \& Rossouw, R. (2016). South Africa's economic policies on unemployment: A historical analysis of two decades of transition. Journal of Economic and Financial Sciences, 9(3), 807-832.

Francis, D., \& Webster, E. (2019). Poverty and inequality in South Africa: critical reflections. Development Southern Africa, 36(1), 788-802.

Frankenberger, T. (1996). Measuring household livelihood security: an approach for reducing absolute poverty. Food Forum, No. 34. Washington, DC, USA.

Fuhrmann, R. C. (2013). Okun's law: Economic growth and unemployment. Retrieved 19th March 2020, from www.investopedia.com/articles/economics/12/okun-law.asp

Graham, L. (2019). Youth unemployment in South Africa: understanding the challenge and working on solutions. Report on Youth and Intergenerational transmission. Retrieved 18th March 2020, from http://www.ci.uct.ac.za/sites/default/files/image_tool/images/367/Child_Gauge/South_African_Child_Gauge_2 015/Child_Gauge_2015-Unemployment.pdf

Grimm, D., Saxena, R., Kubzansky, M., \& Dassel, K. (2013). Preparing the Poor and Vulnerable for Digital Jobs: Lessons from Eight Promising Demand-led Training Models, Monitor. Retrieved 8th August 2020, from https://www.rockefellerfoundation.org/app/uploads/Preparing-the-Poor-andVulnerable-for-Digital-Jobs.pdf

Leedy, P. L., \& Ormrod, J. E. (2014). Practical research planning and design (10th ed.). London: Pearson Publishers.

Maswanganyi, N. (2015). Youth unemployment has worsened since 2008. Business Day, 29 June 2015. Retrieved 20th 
http://www.bdlive.co.za/national/labour/2015/06/29/youth-unemployment-hasworsenedsince-2008-stats-sa-repo rt-shows

McKernan, S., \& Ratcliffe, C. Transition Events in the Dynamics of Poverty: A Review of Issues and Results. Washington, D.C.: The Urban Institute.

Meyer, D. F. (2014). Job creation, a mission impossible? The South African case. Mediterranean Journal of Social Science, 5(16), 65-77.

Mosala, S. J., Venter, J. C. M., \& Bain, E. G. (2017). South Africa's Economic Transformation Since 1994: What Influence has the National Democratic Revolution (NDR) Had?. The Review of Black Political Economy, 44(1), $327-340$

National Youth Development Agency. (2018). Integrated Youth Development Strategy for South Africa. Pretoria: Government Printer.

Psacharopoulos, G., \& Woodhall, M. (1997). Education for Development: An Analysis of Investment Choice. New York: Oxford University Press.

Ramaphosa, C. (2020). Ramaphosa focuses on 6 key areas to fix youth unemployment. Retrieved 27th April 2020, from https://city-press.news24.com/News/ramaphosa-focuses-on-6-key-areas-to-fix-youth-unemployment-20200214

Republic of South Africa. (2009). Statistics South Africa. Men, women and children: findings of the living conditions survey 2009. Pretoria: Government Printer.

Republic of South Africa. (2015). Statistics South Africa. Men, women and children: findings of the living conditions survey 2015. Pretoria: Government Printer.

Republic of South Africa. (2015). Statistics South Africa. Quarterly labour force survey 2015. Pretoria: Government Printer.

Republic of South Africa. (2016). Statistics South Africa. Quarterly labour force survey 2016. Pretoria: Government Printer.

Republic of South Africa. (2017). Statistics South Africa. Quarterly labour force survey 2017. Pretoria: Government Printer.

Republic of South Africa. (2018). Statistics South Africa. General household survey 2018. Pretoria: Government Printer.

Republic of South Africa. (2018). Statistics South Africa. Quarterly labour force survey 2018. Pretoria: Government Printer.

Republic of South Africa. (2019). Department of Trade and Industry (DTI). The National Youth Economic Empowerment Strategy and Implementation Framework. Pretoria: Government Printer.

Republic of South Africa. (2019). Statistics South Africa. Quarterly labour force survey 2019. Pretoria: Government Printer.

Republic of South Africa. (2020). Statistics South Africa. Quarterly labour force survey 2020. Pretoria: Government Printer.

SA News. (2020). SA risks losing 7 million jobs, reaching over 50\% unemployment: Treasury's grim worst-case scenario. Retrieved 29th April 2020, from https://www.news24.com/Tags/Topics/unemployment

Shanker, V., Cooper, A., \& Koi, H. (2015). Unemployment in South Africa. The Rochfeller Foundation: FSG.

Singh, P. K., \& Chudasama, H. (2020). Evaluating poverty alleviation strategies in a developing country. PLoS ONE, 15(1), e0227176. https://doi.org/10.1371/journal.pone.022717

Van der Westhuizen, M., \& Swart, I. (2015). The struggle against poverty, unemployment and social injustice in present-day South Africa: Exploring the involvement of the Dutch Reformed Church at congregational level. Stellenbosch Theological Journal, 1(2), 731-759.

Webster, D. (2019). Unemployment in South Africa is worse than you think. Mail \& Guardian. Retrieved 27th April 2020, from https://mg.co.za/article/2019-08-05-unemployment-in-south-africa-is-worse-than-you-think/

World Bank. (2013). Jobs, a world development report. Washington, DC. 
World Bank. (2015). Jobs and South Africa's Changing Demographics, August 2015. Retrieved 26th April, 2020, from

http://documents.worldbank.org/curated/en/2015/08/24910225/south-africa-economic-update-jobs-southafrica\% E2\%80\%99s-changing-demographics

World Bank. (2018). Overcoming poverty and inequality in South Africa: an assessment of drivers, constraints and opportunities. International Bank for Reconstruction and Development: The World Bank.

World Bank. (2019). Youth employment in Sub-Saharan Africa. IBRD:IDA. The World Bank Group. Retrieved 19th March 2020,

from https://www.worldbank.org/en/programs/africa-regional-studies/publication/youth-employment-in-sub-saharanafrica

\section{Copyrights}

Copyright for this article is retained by the author(s), with first publication rights granted to the journal.

This is an open-access article distributed under the terms and conditions of the Creative Commons Attribution license (http://creativecommons.org/licenses/by/4.0/). 